
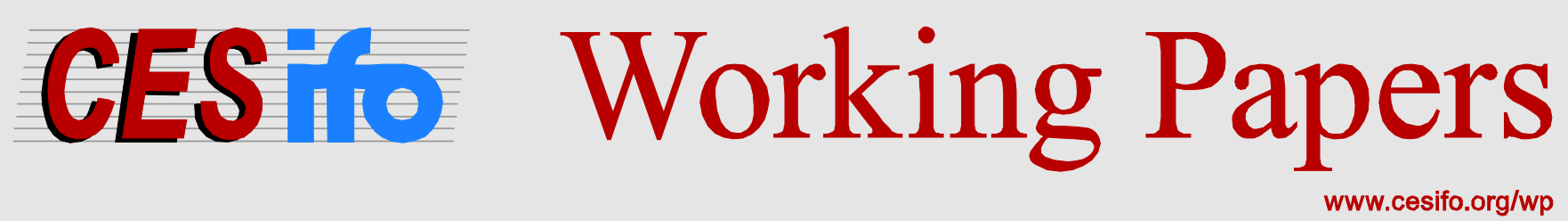

\title{
Evidence on the Political Principal-Agent Problem from Voting on Public Finance for Concert Halls
}

\author{
Niklas Potrafke
}

CESIFO WORKING PAPER NO. 4306

CATEgory 2: Public CHOICE

JUNE 2013

An electronic version of the paper may be downloaded

- from the SSRN website:

- from the RePEc website:

- from the CESifo website:

WWw.SSRN.com

www.RePEc.org

www.CESifo-group.org/wp

\section{CESifo}




\title{
Evidence on the Political Principal-Agent Problem from Voting on Public Finance for Concert Halls
}

\begin{abstract}
Principal-agent problems can arise when preferences of voters are not aligned with preferences of political representatives. Often the consequence of the political principal-agent problem is political catering to special interests. In this paper I provide examples of principalagent problems regarding public spending. The examples concern construction or extension of concert halls in two German cities. Resistance to public funding for the concert halls was particularly strong in electoral districts with large constituencies on the left. The evidence indicates that political representatives were more bourgeois than their constituencies. In the cases studied asymmetric information did not prevail and voters were able to discipline their representatives through referenda that countered the results of voting by political representatives.
\end{abstract}

JEL-Code: D720, D780, H720, Z100.

Keywords: principal-agent problem, referendum, direct democracy, political representation, political ideology, cultural policy.

\author{
Niklas Potrafke \\ Ifo Institute - Leibniz-Institute \\ for Economic Research \\ at the University of Munich \\ Department of Public Finance \\ Poschingerstraße 5 \\ Germany - 81679 Munich \\ potrafke@ifo.de
}

24 June 2013 


\section{Introduction}

The principal-agent problem can arise when voters and their elected representative have different objectives or preferences. The problem is often stated with reference to politicians catering to special interests (see Barro 1973 and for an overview of the literature Hillman 2009, chapter 2). Evidence on the principal-agent problem includes regulation, protectionist policies and staff growth in international organizations (Peltzman 1976; Hillman 1982; Grossman and Helpman 1994; Vaubel 2006; Vaubel et al. 2007). It is possible for voters to successfully respond to the principal-agent problem: a documented case is voting on the EU Constitution or Constitutional Treaty in 2004. The representatives of the then 25 member states of the European Union signed the Treaty on 29 October 2004 in Rome. The Treaty was expected to become effective in November 2006. In May and June 2005, French and Dutch voters voted against approving the Treaty in national referenda. Voters' preferences overrode the objectives of European politicians and bureaucracy and the ratification process stopped. The Treaty of Lisbon subsequently replaced the Constitutional Treaty.

I consider the principal-agent problem in the context of public spending on cultural facilities. Evidence on the nexus between political ideology and spending on culture is not clear-cut (Schulze and Rose 1998; Getzner 2002; Werck et al. 2008; Dalle Nogare and Galizzi 2011; Potrafke 2011a, 2011b; De Witte and Geys 2011; Benito et al. 2013; Noonan 2007; Lewis and Rushton 2007). ${ }^{2}$ Rightwing voters might however be expected to support public spending on traditional cultural events such as concerts, theatres, operas and art exhibitions more so than leftwing voters (see Schulze and Ursprung 2000). Leftwing voters, if they have low incomes, may be able to afford highbrow cultural events only when the government subsidizes the arts. In the United States, for example, voters aligned with the Democrats have

\footnotetext{
2 Rightwing governments spent more on universities than leftwing governments in the German states (Oberndorfer and Steiner 2007; Potrafke 2011a). Schulze's (2008) results suggest that conservative politicians spent more on research in relative terms. The reason may well be that the clientele of leftist parties profit relatively little from public spending on higher education. In Switzerland, social democratic ideology has had a negative influence on privatizing education (Merzyn and Ursprung 2005).
} 
been shown to support subsidizing cultural institutions more strongly than declared Republicans (Brooks 2001, 2004; Rushton 2005; Lewis and Rushton 2007). Leftwing voters with high incomes might vote to support public finance for cultural events on the grounds of bringing culture to the lower-income population.

I examine whether voter preferences correspond with the preferences of their political representatives. I use data on voting by political representatives and on direct voting in referenda with regard to public spending on construction or extension of concert halls in two German cities. ${ }^{3}$ Referenda are uncommon in Germany. Empirical studies show that public spending and debt decrease when voters can influence public spending vis-à-vis their representatives. That is, voters' preferences are better transmitted by direct than representative democracy (e.g., Feld et al. 2008, 2010a, 2010b; Feld and Kirchgässner 2001; Feld et al. 2011; Matsusaka 2005). Voters' preferences expressed in the referenda were contrary to decisions taken by political representatives. The evidence suggests that the principal-agent problems were due to political representatives being more bourgeois than their constituencies.

Principal-agent problems are usually predicated on asymmetric information that permits political representatives to take decisions counter to voters' interests. In the cases studied in this paper, representatives made a decision to fund the concert halls, and subsequent referenda overturned those decisions. The issues were sufficiently salient to evoke voter resistance.

\section{Empirical analysis}

\subsection{Data and variables}

The data for this study is on the voting outcome of the referenda on the construction of the concert hall in Konstanz on March 21, 2010 and on the extension of the concert/congress hall

\footnotetext{
${ }^{3}$ Getzner (2004) and Rushton (2005) investigate the influence of political ideology on cultural policy referenda in Austria and the United States.
} 
in Heidelberg on July 25, 2010. The referenda were independent of one another. Konstanz and Heidelberg are midsize cities in the south west of Germany. The dataset for the referendum in Konstanz contains 65 observations for all electoral districts. Voters were asked whether they agree to the building of a concert hall in the area „Klein-Venedig“, which is located directly at the shore of Lake Konstanz. The cost of construction volume was approximately 48 million Euros, about $25 \%$ of the city's annual budget. ${ }^{4}$ The dataset for the referendum in Heidelberg contains 59 observations for all electoral districts (the appendix provides a list of the electoral districts and boroughs in both cities). Voters were asked whether they agree on extending the existing concert/congress hall located in the city center of Heidelberg (Altstadt). The construction cost was approximately 26 million Euros, about 5\% of the city's annual budget. I use ballot box votes. Voters are required to cast their ballots in the electoral district in which they live.

In both cities, a significant majority voted against the construction/extension of the concert halls: in Konstanz, 20.800 voters $(65.7 \%)$ voted against and 10.875 voters $(34.2 \%)$ voted for the construction of the concert hall. ${ }^{5}$ The voting turnout was $52.2 \%$. The referendum is effectual (quorum 25\%). The concert hall will not be built. In Heidelberg, 26.324 voters $(67.1 \%)$ voted against and 12.911 voters $(32.9 \%)$ voted for the extension of the concert/congress hall. ${ }^{6}$ The voting turnout was $38.9 \%$. The referendum is effectual (quorum 25\%). The concert/congress hall would not be extended. Figure 1 and 2 show the share of "No's" of actual votes in the individual boroughs in Konstanz and Heidelberg.

The clear-cut result is surprising for two reasons: (1) the mayors initiated the projects and (2) voters in both cities traditionally esteem cultural activities. The opinion poll by Findeisen and Hinz (2011) and local newspaper articles document why voters did not support

\footnotetext{
${ }^{4}$ On private demand for public subsidies to the arts see, e.g., Pommerehne and Schneider (1983).

${ }^{5}$ This includes 6.714 postal voters. Voting behavior between postal and ballot box voters was very similar: $62.7 \%$ of the postal voters and $66.5 \%$ of the ballot box voters voted against the proposal.

${ }^{6}$ This includes 8.528 postal voters. Voting behavior between postal and ballot box voters was very similar: $68.2 \%$ of the postal voters and $66.6 \%$ of the ballot box voters voted against the proposal.
} 
the construction/extension of the concert halls. I investigated all articles and letters to the editors on the referenda published 2009 and 2010 in the "Südkurier" (Konstanz) and the "Rhein-Neckar-Zeitung" (Heidelberg). ${ }^{7}$ An important reason for the vote against the construction of the concert hall in Konstanz was the location. Many voters would likely have voted in favor of a concert hall in Konstanz but disagreed with the location directly at the shore of the Lake Konstanz. Voters in Heidelberg did not agree with the cost and the location. Opponents of the extension of the concert/congress hall in the city center argued that too many trees would need to be cut down. Many conservative and liberal voters were also concerned about monument protection.

\footnotetext{
${ }^{7}$ I am grateful to Angelika Speck from the "Südkurier" and Rainer Wesch from the "Rhein-Neckar-Zeitung" collecting all the articles. I investigated 150 articles and 91 letters to the editors published in the "Südkurier" and 78 articles and 68 letters to the editors published in the "Rhein-Neckar-Zeitung". $16 \%$ of the articles and letters to the editors in the "Südkurier" and $12 \%$ in the "Rhein-Neckar-Zeitung" explicitly show that the location and financial volume have influenced the voting behavior to a great deal.
} 
Figure 1. Share of "No's" in the individual boroughs. Konstanz.

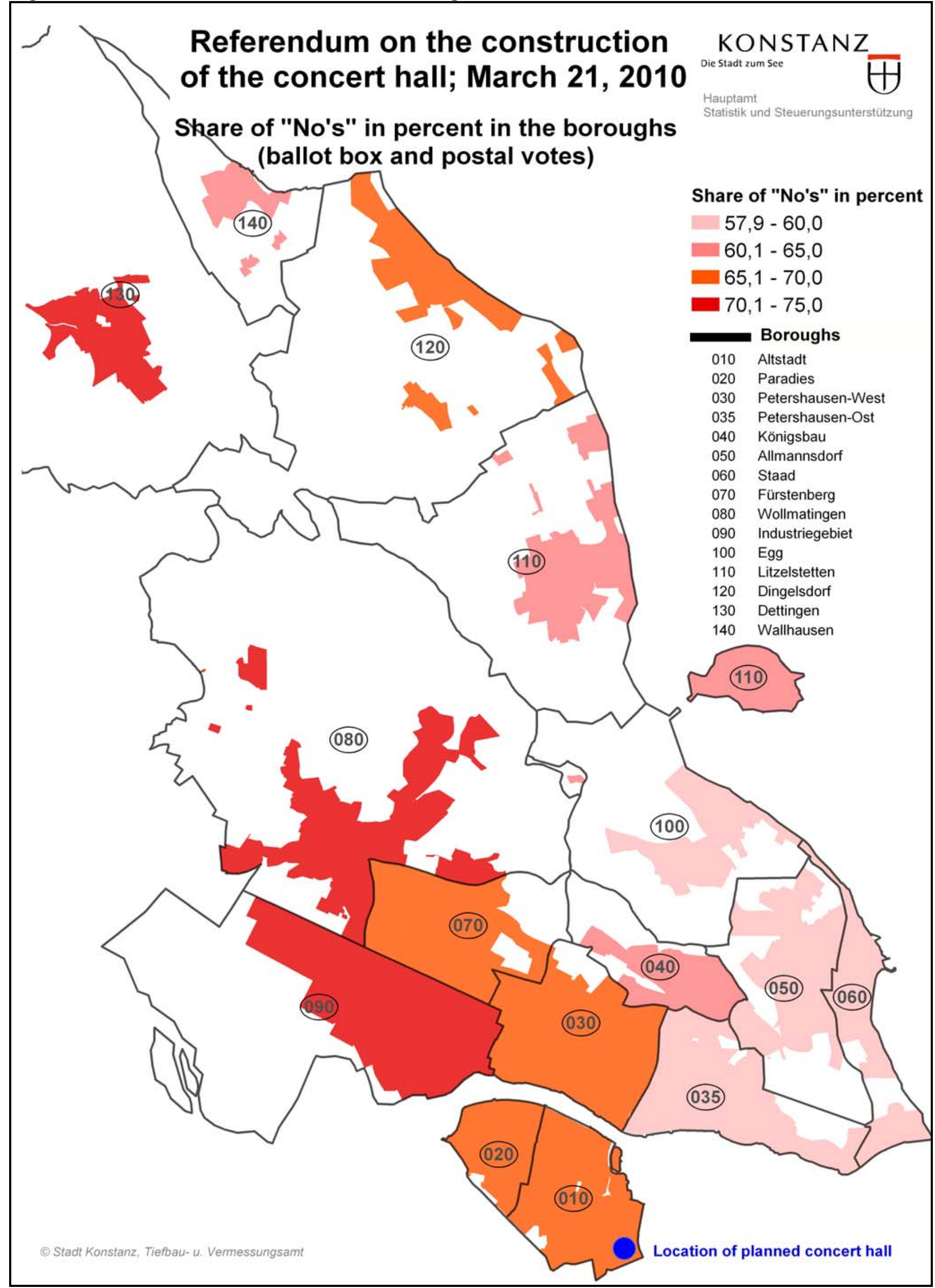


Figure 2. Share of "No's" in the individual electoral districts. Heidelberg.

Referendum on the extension of the congress/concert hall; July 25, 2010

Share of "No's" in percent in the electoral districts (only ballot box)

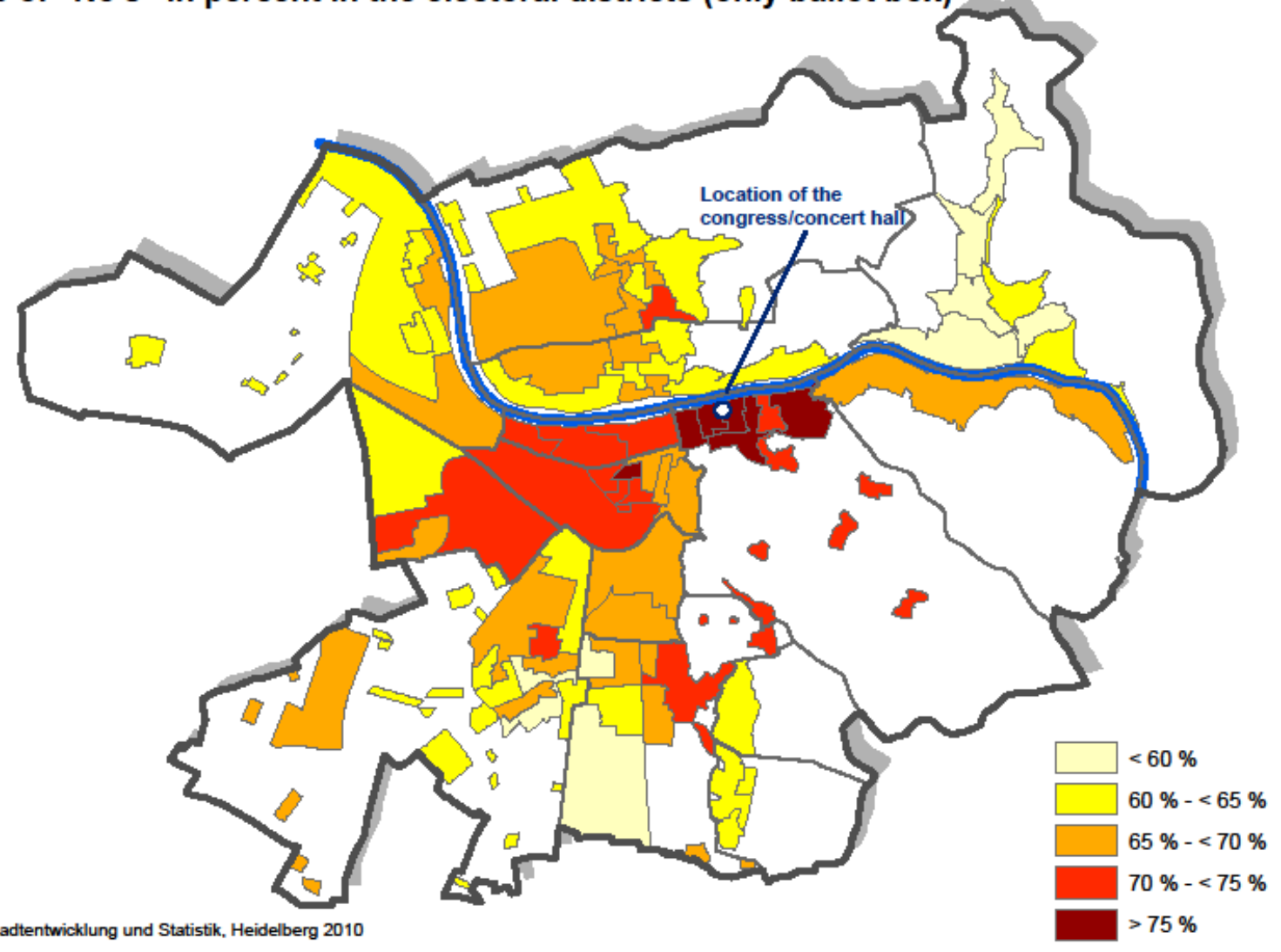


Two major political parties have characterized the political spectrum in Germany: the leftist Social Democratic Party (SPD) and the conservative Christian Democratic Union (CDU). The much smaller Free Democratic Party (FDP) and Green party have played an important role as coalition partners at the federal and state level. The FDP has liberal/marketoriented platforms and the Greens have traditionally followed rather leftwing policies. In Konstanz and Heidelberg, however, the Green party receives disproportionately high support. Both cities have universities and students mostly vote for the Greens. Konstanz was the first city in Germany whose mayor belongs to the Green party. By contrast, the dominant political party in the state of Baden-Wuerttemberg has been the conservative CDU. At the local level, the so called "Free voters" also campaign. The Free Voters have political platforms in the middle of the political spectrum.

The electorate for referenda corresponds with the electorate for local elections. In contrast to German federal and state elections, permanent residents are also allowed to participate in referenda and local elections. ${ }^{8}$ I therefore use the voting turnout of the last local elections held on June 7, 2009 to describe the political preferences in the electoral districts (excluding postal votes). The voting outcome of the local elections in Konstanz was: SPD 18.37\%, CDU 21.55\%, Green 23.54\%, FDP 10.32\%, Free Voters 13.83\%, Leftist Party (Linke Liste Konstanz) 4.96\%, others $7.43 \%$. In Heidelberg, some more political parties compete at the local level than in Konstanz. Eleven parties have seats in the city council in Heidelberg. The Green Party movement is, for example, represented by the "Greens" and the GAL (Grüne Alternative Liste). Similar to the party platforms of the Greens and the GAL are the platforms of the local parties "Heidelberg pflegen und erhalten" and "Generation Heidelberg". The party "Heidelberger" has a conservative/market-oriented platform. There were 94 electoral districts in the local elections held on June 7, 2009, which merged to 59 electoral districts for the referendum held on July 25, 2010. The voting outcome of the local

\footnotetext{
${ }^{8}$ Permanent residents include citizens of other European Union member states who have lived for at least three months in the German municipality in which the election takes place.
} 
elections was: SPD 17.16\%, CDU 19.68\%, Green 25.26\% (Grüne 15.15\% and GAL 10.11\%), FDP $8.60 \%$, Free Voters 5.74\%, Leftist Party (Linke) 5.57\%, "Heidelberg pflegen und erhalten" 3.23\%, "Generation Heidelberg" 6.31\% and the "Heidelberger" 8.45\%.

The voting outcome of the last local elections has been significantly correlated with the share of votes against the construction/extension of the concert halls in both cities. In Konstanz, resistance to the construction of the concert hall was pronounced in electoral districts in which citizens vote for the SPD and the leftist "Linke Liste". By contrast, resistance was much less pronounced in electoral districts in which citizens vote for the CDU and in particular for the FDP. Less resistance occurred in districts in which the "Free Voters" receive strong support. (The correlation coefficients between the share of the individual parties are: SPD 0.51, Linke 0.44, CDU -0.16, FDP -0.56, Free Voters -0.59, Greens 0.07). Advocates of the Greens were divided on the concert hall referendum. On the one hand, the Greens belong to the camp of the political left that strongly opposed the construction of the concert hall; on the other hand, the mayor who initiated building the concert hall belongs to the Green party. The division of the Green explains why the share of leftwing parties (sum of the SPD, Linke Liste and Greens) is indeed positively correlated (correlation coefficient 0.38 ), but the correlation is weaker than considering only the influence of the SPD and the Linke Liste. The correlation coefficient between the share of "No's" and the vote share of rightwing parties (sum of CDU and FDP) is $-0.33 .^{9}$

In Heidelberg, resistance to the extension of the concert/congress hall was not pronounced in electoral districts in which citizens vote for the SPD: the correlation coefficient between the share of the SPD and No's on the referendum is negative ( $\mathrm{r}=-0.19)$. Just as in Konstanz, resistance to the extension of the concert/congress hall was pronounced in electoral

\footnotetext{
${ }^{9}$ I use this distinction because scholars have tested for ideology-induced effects on German economic policymaking by employing left-right dummy variables (e.g, Seitz 2000; Schneider 2010; Potrafke 2012). The reason is that all federal chancellors and state prime ministers have been members of one of these two major blocks, SPD and CDU (CSU in Bavaria) until 2011. German parties can be grouped in a leftwing camp (SPD, Green, Linke) and a rightwing camp (CDU/CSU and FDP).
} 
districts in which citizens vote for the socialist Linke $(\mathrm{r}=0.54)$, whereas resistance was much less pronounced in electoral districts in which citizens vote for the CDU $(r=-0.75)$, for the FDP $(\mathrm{r}=-0.27)$, and for the "Free Voters" $(\mathrm{r}=-0.50)$. While advocates of the Greens were divided on the concert hall referendum in Konstanz, the Greens (Grüne and GAL) strongly opposed the extension of the concert/congress hall in Heidelberg. The correlation coefficient between the share of the Greens and No's on the referendum is 0.68 . I have also investigated the correlation between the share of No's on the referendum and the share of "Heidelberg pflegen und erhalten" $(\mathrm{r}=0.56)$, "Generation Heidelberg" $(\mathrm{r}=0.75)$ and the "Heidelberger" $(\mathrm{r}=-0.43)$. These correlations perfectly correspond with the hypothesis that leftwing parties oppose the extension of the concert/congress hall while rightwing parties are in favor of this project. To better compare the results for Heidelberg with the results for Konstanz, I focus on the influence of the established political parties. Inferences do not change when I consider the parties "Heidelberg pflegen und erhalten", "Generation Heidelberg" and the "Heidelberger" and also disentangle the Green party movement in Grüne and GAL.

The distinction between leftwing parties (sum of the SPD, Linke and Greens) and rightwing parties (sum of CDU and FDP) provides clear-cut results in Heidelberg: the correlation coefficient is 0.75 for the leftwing parties and -0.82 for the rightwing parties.

\subsection{The econometric model}

The baseline econometric model has the following form:

Referendum Vote Share $\left(\mathrm{No}_{\mathrm{i}}=\Sigma_{\mathrm{k}} \alpha_{\mathrm{k}}{ }^{\prime}{ }^{\mathrm{Ideology}}{ }_{\mathrm{ik}}+\Sigma_{1} \beta_{1} \mathrm{X}_{\mathrm{il}}+\mathrm{u}_{\mathrm{i}}\right.$

with $\mathrm{i}=1, \ldots, 65(1, \ldots, 59) ; \mathrm{k}=1, \ldots, 6 ; \mathrm{l}=1 \ldots, 4(1, \ldots .5$,

where the dependent variable Referendum Vote Share $(\mathrm{No})_{\mathrm{i}}$ denotes the share of votes against the construction/extension of the concert hall in electoral district i. I estimate separate models for Konstanz and Heidelberg as baselines. $\Sigma_{\mathrm{k}} \alpha_{\mathrm{k}}{ }^{\prime}$ Ideology' ${ }_{\mathrm{ik}}$ describes the voting share for the individual political parties during the last local election in electoral district i. To avoid perfect 
collinearity between the political party variables, one of the political party variables must function as the reference category (here SPD). Alternatively, I include the share of leftwing parties and rightwing parties; the other parties then function as the reference category. $\Sigma_{1} \beta_{1} X_{i l}$ contains four exogenous control variables for the referendum in Konstanz: I include the overall voting turnout (in $\%$ of the eligible voters) and the number of eligible voters in every electoral district. The overall voting turnout controls for public interest in the referendum. The number of eligible voters in every electoral district controls for the size of the electoral district. The electoral districts are quite small. For this reason, no other economic control variables such as income per capita or education levels are available at the electoral district level. Data on retail buying power is however available on borough level for the year $2010 .{ }^{10} \mathrm{I}$ include this retail buying power variable as a proxy for income. "Neighbor" variable that assumes the value one for the electoral districts that are geographically close to the location where the concert hall should have been built and zero otherwise. The influence of the neighbor variable is ambiguous ex ante. Voters who live close to the suggested location may vote against the proposal because congestion might increase traffic associated with the concert hall. Parking is very restrictive in Konstanz' city center. By contrast, a new concert hall may increase the value of property in the neighborhood (Clark and Kahn 1988). $\Sigma_{1} \beta_{1} X_{\text {il }}$ contains five exogenous control variables for the referendum in Heidelberg: the overall voting turnout (in $\%$ of the eligible voters), the number of eligible voters in every electoral district, and a neighbor district dummy variable. ${ }^{11}$ Data on education and unemployment is available on borough level for the year 2010. I therefore include the share of population with a university degree and unemployment (as a share of total population). Data on income are not

\footnotetext{
${ }^{10}$ Retail buying power is the buying power a person has for retail sales. Retail buying power is based on household income. More information is available at: http://www.gfk-geomarketing.de/marktdaten/marktdaten_nach_thema/einzelhandelskaufkraft.html ${ }^{11}$ I assign as neighbors the electoral districts in the boroughs "A- 1 tstadt" and "Paradies" in Konstanz and "Altstadt" in Heidelberg.
} 
available. The unemployment variable is however likely to consider an income-induced effect. $u_{i}$ describes an error term.

Table 1 presents descriptive statistics of all variables included. I estimate the models with ordinary least squares (OLS) with robust standard errors. 
Table 1: Descriptive Statistics.

\begin{tabular}{|c|c|c|c|c|c|c|}
\hline Variable & Obs. & Mean & Std. Dev. & Min & Max & Source \\
\hline \multicolumn{7}{|l|}{ Konstanz } \\
\hline No's (share) & 65 & 67.01 & 6.64 & 46.63 & 78.87 & Electoral Office Konstanz \\
\hline SPD & 65 & 18.37 & 3.60 & 10.56 & 26.34 & Electoral Office Konstanz \\
\hline Green & 65 & 23.54 & 6.10 & 8.62 & 38.05 & Electoral Office Konstanz \\
\hline Linke Liste (left) & 65 & 4.96 & 2.30 & 1.53 & 11.82 & Electoral Office Konstanz \\
\hline CDU & 65 & 21.55 & 6.00 & 10.70 & 36.34 & Electoral Office Konstanz \\
\hline FDP & 65 & 10.32 & 2.27 & 6.31 & 16.42 & Electoral Office Konstanz \\
\hline Free Voters & 65 & 13.83 & 3.34 & 7.53 & 21.86 & Electoral Office Konstanz \\
\hline Other & 65 & 7.43 & 2.38 & 3.39 & 14.94 & Electoral Office Konstanz \\
\hline Leftwing parties & 65 & 46.87 & 8.59 & 26.75 & 67.27 & Electoral Office Konstanz \\
\hline Rightwing parties & 65 & 31.86 & 6.74 & 18.78 & 51.02 & Electoral Office Konstanz \\
\hline Turnout (share) & 65 & 47.19 & 9.90 & 27.60 & 63.30 & Electoral Office Konstanz \\
\hline Eligible Voters & 65 & 934.72 & 175.65 & 473 & 1353 & Electoral Office Konstanz \\
\hline Neighbor district & 65 & 0.22 & 0.41 & 0 & 1 & Own calculation \\
\hline Retail buying power & 65 & 5239.69 & 493.07 & 4035 & 6323 & Statistical Office Konstanz \\
\hline Protestant (share) & 65 & 24.31 & 1.74 & 20.95 & 27.62 & $\begin{array}{l}\text { Statistical Office Konstanz } \\
\text { (own calculation) }\end{array}$ \\
\hline Catholic (share) & 65 & 40.17 & 2.99 & 34.20 & 49.28 & $\begin{array}{l}\text { Statistical Office Konstanz } \\
\text { (own calculation) }\end{array}$ \\
\hline Other Religion (share) & 65 & 1.01 & 0.46 & 0.29 & 3.76 & $\begin{array}{l}\text { Statistical Office Konstanz } \\
\text { (own calculation) }\end{array}$ \\
\hline No Religion (share) & 65 & 34.42 & 3.37 & 26.53 & 43.60 & $\begin{array}{l}\text { Statistical Office Konstanz } \\
\text { (own calculation) }\end{array}$ \\
\hline High-Income dummy & 65 & 0.31 & 0.47 & 0 & 1 & own calculation \\
\hline \multicolumn{7}{|l|}{ Heidelberg } \\
\hline No's (share) & 59 & 66.63 & 5.83 & 53.23 & 78.45 & Electoral Office Heidelberg \\
\hline SPD & 59 & 17.16 & 4.64 & 8.51 & 35.12 & Electoral Office Heidelberg \\
\hline Green (Grüne+GAL) & 59 & 25.26 & 6.65 & 11.26 & 35.66 & Electoral Office Heidelberg \\
\hline Linke (left) & 59 & 5.57 & 1.79 & 1.80 & 11.89 & Electoral Office Heidelberg \\
\hline $\mathrm{CDU}$ & 59 & 19.68 & 5.33 & 12.48 & 33.57 & Electoral Office Heidelberg \\
\hline FDP & 59 & 8.60 & 2.02 & 5.24 & 15.83 & Electoral Office Heidelberg \\
\hline Free Voters & 59 & 5.74 & 2.30 & 2.80 & 11.95 & Electoral Office Heidelberg \\
\hline Die Heidelberger & 59 & 8.45 & 3.89 & 3.88 & 20.82 & Electoral Office Heidelberg \\
\hline Generation Heidelberg & 59 & 6.31 & 2.45 & 2.90 & 12.10 & Electoral Office Heidelberg \\
\hline Heidelberg erhalten & 59 & 3.23 & 1.60 & 0.95 & 7.89 & Electoral Office Heidelberg \\
\hline Leftwing parties & 59 & 47.99 & 6.15 & 35.00 & 61.84 & Electoral Office Heidelberg \\
\hline Rightwing parties & 59 & 28.28 & 5.52 & 18.23 & 42.07 & Electoral Office Heidelberg \\
\hline Turnout (share) & 59 & 31.63 & 6.73 & 13.8 & 45.4 & Electoral Office Heidelberg \\
\hline Eligible Voters & 59 & 1715.88 & 581.48 & 868 & 2938 & Electoral Office Heidelberg \\
\hline Neighbor district & 59 & 0.12 & 0.33 & 0 & 1 & Own calculation \\
\hline University degree (share) & 59 & 32.31 & 11.76 & 8.4 & 51.4 & Electoral Office Heidelberg \\
\hline Unemployment rate & 59 & 2.60 & 1.10 & 1.10 & 6.15 & Electoral Office Heidelberg \\
\hline Protestant (share) & 59 & 32.19 & 3.34 & 23.89 & 37.35 & Electoral Office Heidelberg \\
\hline Catholic (share) & 59 & 27.68 & 2.36 & 25.61 & 33.53 & Electoral Office Heidelberg \\
\hline Other Religion (share) & 59 & 0.98 & 0.35 & 0.58 & 2.01 & Electoral Office Heidelberg \\
\hline
\end{tabular}




\subsection{Basic regression results}

Table 2 shows the regression results for Konstanz. Columns (1) and (2) show the results when no control variables are included, in columns (3) and (4) the control variables are included. I present results including/excluding the control variables to show that the results regarding the political variables are not sensitive to including/excluding the control variables. In columns (1) and (3) political ideology is measured by the individual party vote shares, in column (2) and (4) political ideology is measured by the vote shares for leftwing and rightwing parties. The control variables in column (3) do not turn out to be statistically significant. In column (4), voting turnout is statistically significant at the $1 \%$ level and indicates that the shares of "No's" decreases by about 0.25 percentage points, when voting turnout increased by one percentage point. ${ }^{12}$ By contrast, the political party variables in columns (1) and (3) have a significant influence on the referendum's voting outcome. The FDP variables are statistically significant at the $1 \%$ level. The numerical meaning of the coefficients is that a corresponding increase of the voting share for the FDP by one percentage point would decrease the No's share in the referendum by about 1.3 percentage points. The Free Voters variables are also statistically significant at the $1 \%$ level, the Green variables at the 5\% level in column (1) and at the $10 \%$ level in column (3), the variable Other at the $10 \%$ level in column (1). The numerical meaning of the coefficients is that a corresponding increase of the voting share for the Free Voters and Greens by one percentage point would decrease the No's share in the referendum by about 1.05 and 0.50 percentage points. The numerical meaning of the coefficients of the variable Other is that a corresponding increase of the voting share for the other parties by one percentage point would increase the No's share in the referendum by about 0.6 percentage points. Consequently, the results show that resistance to the construction of the concert hall was less severe in electoral districts where citizens vote for the FDP, Free

\footnotetext{
${ }^{12}$ This effect is plausible because the dependent variable is measured as share of "No's" of actual votes. Voting turnout is measured as share of actual votes on eligible voters. Voting turnout has a positive influence on the "No's" as a share of eligible voters. I refer to this effect in section 2.4
} 
Voters, and Greens compared to electoral districts where citizens vote for the SPD. The Linke Liste and CDU variables do however not turn out to be statistically significant.

Evaluating the ideology-induced effects on a left-right scale does not indicate that political ideology influenced the voting behavior. The variable "Leftwing parties" and "Rigthwing parties" in columns (2) and (4) do not turn out to be statistically significant. The reason is the non-partisan behavior and the high vote share of the Greens. The fit of the model is however much better in columns (1) and (3) when the individual party variables are included, implying that the individual party variables explain a great deal of the variation in the No's share in the referendum. 
Table 2: Regression Results. Ordinary Least Squares (OLS) with robust standard errors. Dependent variable: share of No's on concert hall referendum. Konstanz.

\begin{tabular}{|c|c|c|c|c|}
\hline & (1) & (2) & (3) & (4) \\
\hline Linke Liste (left) & $\begin{array}{c}-0.4574 \\
{[1.16]}\end{array}$ & & $\begin{array}{c}-0.4837 \\
{[1.13]}\end{array}$ & \\
\hline CDU & $\begin{array}{c}-0.2451 \\
{[0.78]}\end{array}$ & & $\begin{array}{c}-0.2088 \\
{[0.62]}\end{array}$ & \\
\hline FDP & $\begin{array}{c}-1.3349 * * * \\
{[3.02]}\end{array}$ & & $\begin{array}{c}-1.2958 * * * \\
{[2.88]}\end{array}$ & \\
\hline Free Voters & $\begin{array}{c}-1.0700^{* * *} * \\
{[5.62]}\end{array}$ & & $\begin{array}{c}-1.0250 * * * \\
{[4.24]}\end{array}$ & \\
\hline Green & $\begin{array}{c}-0.5168^{* *} \\
{[2.16]}\end{array}$ & & $\begin{array}{c}-0.4903^{*} \\
{[1.87]}\end{array}$ & \\
\hline Other & $\begin{array}{c}0.6032 * \\
{[1.80]}\end{array}$ & & $\begin{array}{l}0.5723 \\
{[1.58]}\end{array}$ & \\
\hline Leftwing parties & & $\begin{array}{l}0.3721 \\
{[1.56]}\end{array}$ & & $\begin{array}{l}0.1133 \\
{[0.40]}\end{array}$ \\
\hline Rightwing parties & & $\begin{array}{c}0.108 \\
{[0.33]}\end{array}$ & & $\begin{array}{c}-0.0156 \\
{[0.04]}\end{array}$ \\
\hline Voting Turnout & & & $\begin{array}{c}-0.0415 \\
{[0.49]}\end{array}$ & $\begin{array}{c}-0.2514 * * * \\
{[2.72]}\end{array}$ \\
\hline Eligible Voters & & & $\begin{array}{c}-0.0024 \\
{[0.71]}\end{array}$ & $\begin{array}{l}-0.007 \\
{[1.35]}\end{array}$ \\
\hline Neighbor district & & & $\begin{array}{l}0.3337 \\
{[0.19]}\end{array}$ & $\begin{array}{c}-0.1992 \\
{[0.10]}\end{array}$ \\
\hline Retail buying power & & & $\begin{array}{c}-0.0003 \\
{[0.26]}\end{array}$ & $\begin{array}{l}-0.002 \\
{[1.17]}\end{array}$ \\
\hline Constant & $\begin{array}{c}110.8088^{* * *} \\
{[5.99]} \\
\end{array}$ & $\begin{array}{c}46.1219 * * \\
{[2.19]}\end{array}$ & $\begin{array}{c}114.7041^{* * *} \\
{[5.26]} \\
\end{array}$ & $\begin{array}{c}91.4043^{* * *} \\
{[3.18]} \\
\end{array}$ \\
\hline $\begin{array}{l}\text { Observations } \\
\text { R-squared }\end{array}$ & $\begin{array}{c}65 \\
0.59\end{array}$ & $\begin{array}{c}65 \\
0.15\end{array}$ & $\begin{array}{c}65 \\
0.60\end{array}$ & $\begin{array}{c}65 \\
0.27\end{array}$ \\
\hline
\end{tabular}


Table 3 shows the regression results for Heidelberg. The neighbor district dummy variable is statistically significant at the $1 \%$ level in columns (3) and (4) and indicates that the share of "No's" was about five percentage points higher in the electoral districts in the city center than in the other boroughs. Resistance to the extension of the concert/congress hall was thus pronounced in the electoral districts surrounding the concert/congress hall. ${ }^{13}$ The unemployment rate is statistically significant at the $1 \%$ level in column (4) and has the expected positive sign: the coefficient indicates that the share of "No's" was about 1.8 percentage points higher when the unemployment rate increases by one percentage point. This finding implies that unemployed persons do not prefer to have tax money spent on cultural affairs. The other control variables do not turn out to be statistically significant.

The political party variables in columns (1) and (3) have a significant influence on the referendum's voting outcome. The coefficient of the Linke (left) variable has the expected positive sign and is statistically significant at the $5 \%$ level in column (1), but lacks statistical significance in column (3). The numerical meaning of the coefficient in column (1) is that a corresponding increase of the voting share for the Linke by one percentage point would increase the No's share in the referendum by about 0.77 percentage points. The coefficient of the CDU variable has the expected negative sign and is statistically significant at the $1 \%$ level in column (1) and at the $5 \%$ level in column (3). The numerical meaning of the coefficients is that a corresponding increase of the voting share for the CDU by one percentage point would decrease the No's share in the referendum by about 0.57 percentage points. The coefficient of the FDP variable has the expected negative sign and is statistically significant at the $1 \%$ level in columns (1) and (3). The numerical meaning of the coefficients is that a corresponding increase of the voting share for the FDP by one percentage point would decrease the No's

\footnotetext{
${ }^{13}$ Concert halls are expected to have negative and positive externalities on the neighborhood. In fact, it is likely that the value of properties in the neighborhood increases when a brand-new concert hall is built (positive externality - in Konstanz). This positive externality is likely to be smaller when an existing concert hall is extended (Heidelberg). In Heidelberg, the negative externalities appear to over compensate the small positive externalities.
} 
share in the referendum by about 0.73 percentage points. The coefficients of the Free Voters, Green and Other variables do not turn out to be statistically significant. The results show that resistance to the extension of the concert/congress hall was less severe in electoral districts where citizens vote for the CDU and the FDP, and more severe in electoral districts where citizens vote for the Linke compared to electoral districts where citizens vote for the SPD.

In contrast to the results from Konstanz, evaluating the ideology-induced effects on a left-right scale also shows that political ideology has strongly influenced the voting behavior in Heidelberg. The coefficient of the variable "Leftwing parties" has the expected positive sign and is statistically significant at the $10 \%$ level in column (4); it however lacks statistical significance in column (2). The numerical meaning of the coefficient in column (4) is that a corresponding increase of the voting share for the leftwing parties by one percentage point would increase the No's share in the referendum by about 0.3 percentage points. The coefficient of the variable "Rightwing parties" has the expected negative sign and is statistically significant at the $1 \%$ level in column (2) and at the 5\% level in column (4). The numerical meaning of the coefficient in column (4) is that a corresponding increase of the voting share for the rightwing parties by one percentage point would decrease the No's share in the referendum by about 0.6 percentage points. 
Table 3: Regression Results. Ordinary Least Squares (OLS) with robust standard errors. Dependent variable: share of No's on concert hall referendum. Heidelberg.

\begin{tabular}{|c|c|c|c|c|}
\hline & (1) & (2) & (3) & (4) \\
\hline Linke (left) & $\begin{array}{c}0.7734 * * \\
{[2.35]}\end{array}$ & & $\begin{array}{l}0.2778 \\
{[0.90]}\end{array}$ & \\
\hline $\mathrm{CDU}$ & $\begin{array}{c}-0.6783 * * * \\
{[2.69]}\end{array}$ & & $\begin{array}{c}-0.4726^{* *} \\
{[2.02]}\end{array}$ & \\
\hline FDP & $\begin{array}{c}-0.7571 * * * \\
{[4.27]}\end{array}$ & & $\begin{array}{c}-0.7177 * * * \\
{[3.20]}\end{array}$ & \\
\hline Free Voters & $\begin{array}{l}-0.209 \\
{[0.67]}\end{array}$ & & $\begin{array}{c}-0.4825 \\
{[1.50]}\end{array}$ & \\
\hline Green & $\begin{array}{l}0.0649 \\
{[0.33]}\end{array}$ & & $\begin{array}{l}0.2532 \\
{[1.28]}\end{array}$ & \\
\hline Other & $\begin{array}{c}-0.0454 \\
{[0.23]}\end{array}$ & & $\begin{array}{l}-0.172 \\
{[0.91]}\end{array}$ & \\
\hline Leftwing parties & & $\begin{array}{l}0.1908 \\
{[1.18]}\end{array}$ & & $\begin{array}{c}0.3052^{*} \\
{[1.76]}\end{array}$ \\
\hline Rightwing parties & & $\begin{array}{c}-0.6890 * * * \\
{[3.43]}\end{array}$ & & $\begin{array}{c}-0.4891^{* *} \\
{[2.31]}\end{array}$ \\
\hline Voting Turnout & & & $\begin{array}{c}0.1198 \\
{[1.29]}\end{array}$ & $\begin{array}{c}0.0958 \\
{[1.20]}\end{array}$ \\
\hline Eligible Voters & & & $\begin{array}{l}0.0001 \\
{[0.15]}\end{array}$ & $\begin{array}{c}0.0002 \\
{[0.27]}\end{array}$ \\
\hline Neighbor district & & & $\begin{array}{c}5.5084 * * * \\
{[4.38]}\end{array}$ & $\begin{array}{c}5.3351 * * * \\
{[4.85]}\end{array}$ \\
\hline University degree & & & $\begin{array}{c}-0.0481 \\
{[0.43]}\end{array}$ & $\begin{array}{c}0.0661 \\
{[0.89]}\end{array}$ \\
\hline Unemployment rate & & & $\begin{array}{l}0.7751 \\
{[1.03]}\end{array}$ & $\begin{array}{c}1.8027 * * * \\
{[2.87]}\end{array}$ \\
\hline Constant & $\begin{array}{c}82.5462 * * * \\
{[5.65]}\end{array}$ & $\begin{array}{c}76.9504 * * * \\
{[5.89]}\end{array}$ & $\begin{array}{c}74.8744 * * * \\
{[5.73]} \\
\end{array}$ & $\begin{array}{c}54.9836^{* * *} \\
{[3.49]} \\
\end{array}$ \\
\hline $\begin{array}{l}\text { Observations } \\
\text { R-squared }\end{array}$ & $\begin{array}{c}59 \\
0.75\end{array}$ & $\begin{array}{c}59 \\
0.69\end{array}$ & $\begin{array}{c}59 \\
0.81\end{array}$ & $\begin{array}{c}59 \\
0.79\end{array}$ \\
\hline
\end{tabular}




\subsection{Robustness Checks}

I checked the robustness of the results in several ways. Voting behavior in an individual election district is likely to be influenced by voting behavior in neighboring electoral districts (e.g., Revelli 2008). Figure 1 and 2 show a spatial pattern in the voting behavior on the construction/extension of the concert halls. I have therefore included a spatially lagged dependent variable that considers geographical neighbors. ${ }^{14}$ The spatial weight matrix is rownormalized. I have estimated a spatial lag model using instrumental variables and have regressed the spatially weighted dependent variable on the explanatory and spatially weighted explanatory variables in the first stage. Table 4 shows the results for Konstanz: the coefficients of the spatially lagged dependent variables have a positive sign and are statistically significant at the $10 \%$ level in columns (1) and (3), at the $5 \%$ level in column (2) and at the $1 \%$ level in column (4). The numerical meaning of the coefficients is that a corresponding increase of the No's share in the referendum in the average neighboring electoral district by one percentage point would increase the No's share in the referendum by about 0.7 percentage points. Including the spatially lagged dependent variable does not change the inferences regarding the ideology variables at all. Table 5 shows the results for Heidelberg: the spatially lagged dependent variables do not turn out to be statistically significant. Including the spatially lagged dependent variable does not change the inferences regarding the ideology variables at all.

\footnotetext{
${ }^{14}$ See, for example, Anselin (1988) on the basic econometric models to describe spatial interaction.
} 
Table 4: Regression Results. Two Stage Least Squares (2SLS) with robust standard errors. Dependent variable: share of No's on concert hall referendum. Konstanz.

Spatial Lag included.

(1)

Linke Liste (left)

CDU

FDP

Free Voters

Green

Other

Leftwing parties

Rightwing parties

Voting Turnout

Eligible Voters

Neighbor district

Retail buying power

Spatial Lag

Constant

Observations

R-squared

$$
\text { [1.73] }
$$

(2)

(3)

(4)

$\begin{array}{cc}-0.3506 & -0.3567 \\ {[0.99]} & {[0.87]} \\ -0.2387 & -0.2051 \\ {[0.92]} & {[0.71]} \\ -0.9973^{* * *} & -0.9640^{* *} \\ {[2.80]} & {[2.64]} \\ -0.5997^{*} & -0.6071^{*} \\ {[1.76]} & {[1.93]} \\ -0.3941^{*} & -0.3736^{*} \\ {[1.94]} & {[1.71]} \\ 0.5336^{*} & 0.5006\end{array}$

[1.52]

$$
\begin{gathered}
-0.3368 \\
{[0.79]} \\
-0.4722 \\
{[1.28]}
\end{gathered}
$$$$
\text { [0.53] }
$$$$
-0.2385
$$$$
\text { [0.84] }
$$

$-0.0265$

[0.30]

$-0.0027$

$-0.1381$

[0.81]

0.2009

[0.12]

$-0.0003$

[1.67]

$-0.0055$

[1.39]

$$
\text { [0.25] }
$$

$-0.2372$

[0.15]

$0.4844 *$ $-0.0012$

Absolute value of t statistics in brackets; $*$ significant at $10 \%$

\begin{tabular}{cc}
{$[1.89]$} & {$[2.12]$} \\
$63.6409^{* *}$ & 4.4650 \\
{$[2.33]$} & {$[0.20]$} \\
\hline 65 & 65 \\
0.63 & 0.42
\end{tabular}

[1.83]

$69.5243 * * *$

[2.76]

$[2.70]$

$49.0418 * *$

65
[2.04]

0.63

0.51


Table 5: Regression Results. Two Stage Least Squares (2SLS) with robust standard errors. Dependent variable: share of No's on concert hall referendum. Heidelberg.

Spatial Lag included.

\begin{tabular}{lc}
\hline Linke (left) & $0.6511^{*}$ \\
& {$[1.98]$} \\
CDU & $-0.5802^{* *}$ \\
& {$[2.25]$} \\
FDP & $-0.7065^{* * *}$ \\
& {$[4.13]$} \\
Free Voters & -0.1115 \\
& {$[0.36]$} \\
Green & 0.0394 \\
& {$[0.18]$} \\
Other & 0.0007 \\
& {$[0.00]$}
\end{tabular}

Leftwing parties

Rightwing parties

Voting Turnout

Eligible Voters

Neighbor district

University degree

Unemployment rate

Spatial Lag

Constant
(1)

(2)

(3)

0.2617

[0.84]

$-0.4366^{*}$

[1.84]

$-0.6761 * * *$

[2.80]

$-0.4525$

[1.43]

0.2618

[1.29]

$-0.1416$

[0.84]

0.1434
$[0.94]$
$-0.6379^{* * *}$
$[3.08]$

0.1180

[1.27]

0.0001

[0.12]

$5.2340^{* * *}$

[4.00]

$-0.0672$

[0.56]

0.6375

[0.74]

0.0890

[0.47]

0.1832

[1.46]

$62.3697 * * *$

$65.5837^{* * *}$

$68.1490 * *$

\begin{tabular}{lcccc} 
& {$[3.86]$} & {$[3.63]$} & {$[4.56]$} & {$[2.57]$} \\
\hline Observations & 59 & 59 & 59 & 59 \\
R-squared & 0.76 & 0.71 & 0.8116 & 0.80 \\
\hline Absolute value of t statistics in brackets; * significant at $10 \%$; ** significant at $5 \%$; $* *$ significant at $1 \%$ &
\end{tabular}

(4)

Absolute value of t statistics in brackets; * significant at $10 \%$; ** significant at $5 \%$; ** significant at $1 \%$ 
Further control variables are likely to influence preferences on cultural policy. The reason for the lack of control variables is the small size of the electoral districts. To approximate differences in income I replaced the retail buying power variable by a high income borough dummy variable which assumes the value one for boroughs with many onefamily houses and mansions and zero otherwise. ${ }^{15}$ The high income borough dummy variable does not turn out to be statistically significant when the individual party share variables are used; it is statistically significant with the expected negative sign when the left/right political variables are used. Including the high income borough variable does not change the inferences regarding the political variables (results not shown).

Religion may also influence preferences on cultural policy (e.g. Katz-Gerro et al. 2009). Data on religion in Konstanz are available on borough level for the year 2009. Four categories can be distinguished: Protestants, Catholics, Other Religion and No Religion. I include these religion variables as a share of total population in the respective borough. No Religion is the reference category. Results show that compared to districts where citizens are less religious, resistance to the construction of the concert hall was strong in electoral districts where citizens are Catholic. By contrast, compared to districts where citizens were less religious, Protestants voted more in favor of the project. It turns out that Protestants mostly live in the high income boroughs. Highly qualified individuals who have moved to Konstanz in order work in the Lake Konstanz or Zurich area appear to be Protestants, whereas the local petty bourgeoisie is predominantly Catholic. In any event, including the religion variables does not change the inferences regarding the political variables. Data on religion in Heidelberg are available on borough level for the year 2010. Four categories can be distinguished: Protestants, Catholics, Other Religion and No Information available. The data on "Other Religion" and "No Information" available reveal however that several citizens

\footnotetext{
${ }^{15}$ I am indebted to Eberhard Baier from Statistical Office Konstanz for choosing the boroughs "PetershausenOst", “Allmannsdorf”, "Staad", "Egg”, "Litzelstetten", "Dingelsdorf” and "Wallhausen" as high income boroughs.
} 
having other religions than Protestant and Catholic did not reveal their religion. I therefore include Protestant and Catholic religion as a share of total population and use the remaining categories as reference. Results show that both Catholics and Protestants were more in favor of the project. Including the religion variables does not change the inferences regarding the political variables at all.

Results could be sensitive to the chosen reference category of the political variables because the voting shares of the political parties differ. I have changed the reference category of the political variables. Inferences do not change.

The reported effects could be driven or mitigated by idiosyncratic circumstances in the individual electoral districts. For this reason, I tested whether the results are sensitive to the inclusion/exclusion of particular electoral districts. In both cities, inferences do not change when excluding an individual electoral district.

I have merged the dataset for Konstanz and Heidelberg and estimated joint models similar to the specifications in Tables 2 to 5 (I cannot include retail buying power, the unemployment rate and university degree in the joint models). The results show that the FDP variables are statistically significant at the $1 \%$ or $5 \%$ level across all specifications. The numerical meaning of the coefficients is that a corresponding increase of the voting share for the FDP by one percentage point would decrease the No's share in the referenda by about 0.7 percentage points. The coefficient for the Linke (left) variable has the expected positive sign and is statistically significant at the $5 \%$ level in the baseline specifications, but lacks statistical significance when the spatially lagged dependent variable is included. The coefficient of the variable "Rightwing parties" has the expected negative sign and is statistically significant at the $10 \%$ and $5 \%$ level in the spatial regression model.

I have replaced the dependent variable share of "No's" of actual votes by the share of "No's" of eligible voters. In these regressions, the voting turnout variable is statistically significant at the $1 \%$ level and has a positive sign indicating that voters mostly participated in 
the referenda to vote against the proposals. Inferences regarding the political variables do not change.

\subsection{Voter preferences and political representation}

The direct-democratic vote against the construction/extension of the concert halls contrasts with the voting behavior of the representatives in the city council in both cities. The city council in Konstanz has 40 seats: 10 Green, 9 CDU, 7 SPD, 6 Free Voters, 4 FDP, 2 Linke Liste, 1 “Neue Linie Konstanz” and 1 "Frank und Freie/Bunte Liste Konstanz”. In April 2009, a majority consisting of the CDU, FDP, Free Voters and 5 of the Green council members voted for the construction of the concert hall (24 yes, 15 no, 1 council member did not attend the meeting). The SPD voted as a block against the proposal. This voting behavior accords with the platforms of the political parties on the construction of the concert hall (Stadt Konstanz 2010a, 2010b). In January 2010, the city council decided to initiate a referendum on the construction of the concert hall for two reasons. First, the decision has been regarded to be so important and the financial volume to be so huge that the voters should have a say in it. Second, a referendum could have been initiated by the citizens anyhow by collecting more than 5.000 signatures. ${ }^{16}$ The city council wanted to prevent the citizens from calling a referendum and initiated it itself. The referendum did not result in a majority for the proposal because many conservative and liberal voters did not agree with the location of the concert hall.

The city council in Heidelberg has 41 seats. When the city council voted on the extension of the concert/congress hall in March 2010, the seating was as follows: 9 CDU, 10 Greens (6 Grüne and 4 GAL), 7 SPD, 4 FDP, 3 "Heidelberger", 2 Free Voters, 2 "Generation

\footnotetext{
${ }^{16}$ Citizens can petition referenda. The number of signatures required depends on the number of inhabitants in the cities/communities. http://www.landesrecht-

bw.de/jportal/;jsessionid=F82A3192CD9F70AA4E8E2114612EB12D.jpb4?quelle=jlink\&query=GemO+BW\&p sml=bsbawueprod.psml\&max =true\&aiz=true\#jlr-GemOBWV11P21\%20jlr-GemOBWV8P21\%20jlr-

GemOBWV9P21\%20j1r-GemOBWV10P21 (accessed 24.06.2013).
} 
Heidelberg", 2 Linke Liste, 1 "Heidelberg plegen und erhalten" and the mayor who does not belong to a political party. ${ }^{17}$ A majority consisting of 27 council members voted for the extension of the concert/congress hall, 14 council members voted against it. The vote was not by roll call. Hence one cannot clearly identify which council members voted in favor and against the proposal. It is however very likely that the 7 SPD, 2 Linke Liste, 4 GAL and 1 "Heidelberg plegen und erhalten" council members voted against the proposal, because these factions requested to not extend the concert/congress hall directly before the ultimate vote in the plenary session of the city council. The request was denied by 27 to 14 votes. This voting behavior would be in line with the platforms of the political parties on the extension of the concert/congress hall (Stadt Heidelberg 2011). The party "Grüne" supported extending the concert/congress hall given that additional local parks would be built and tree lines would be supplemented in the Altstadt. In May 2010, the city council decided to initiate a referendum on the extension of the concert hall because citizens have collected 18.000 signatures to initiate a referendum. The mayor concluded that the voters should have a direct say in the extension of the concert/congress hall. ${ }^{18}$

My findings thus confirm that the voting behavior of political representatives can be decoupled from the preferences of voters in local jurisdictions, in these cases because politicians were more bourgeois than their voters. Indicators of bourgeois preferences are education, family background etc. (empirical studies show that education strongly influences support for arts spending. See, for example, Lewis and Rushton 2007: 109). ${ }^{19}$ I have collected data on education of the city council members in Konstanz and Heidelberg: $65 \%$ of the

\footnotetext{
${ }^{17}$ In 2011, two council members of the GAL joined the „Grüne“ faction. The remaining two council members of the GAL form a working group with the council member from "Heidelberg pflegen und erhalten". The eight council members from the "Grüne" form a faction with the two council members from "Generation Heidelberg". ${ }^{18}$ Scholars investigate types of referenda (required/non-required; active/passive etc). See, for example, Tridimas (2007, 2010), Hug (2004), Hug and Sciarini (2000). The types of referenda discussed by Hug and Tridimas do not include situations as in Konstanz and Heidelberg. One could therefore develop a theoretical model for local referenda. In any event, Hug (2009: 261) concludes “.... an important element still remains unaddressed, namely whether and why the preferences of citizens should be at odds with those legislators". I elaborate on this issue.

${ }^{19}$ Education and income have been used to measure politicians' competence. Besley et al. (2013) measure political competence by the earnings potential outside the political market, conditional on education and occupation.
} 
council members in Konstanz and $71 \%$ in Heidelberg have a university degree. $37 \%$ of the persons included in the opinion poll sample by Findeisen and Hinz (2011) in Konstanz have a university degree. In Heidelberg, 30.6\% of the employees in 2009 had a university degree. These figures show that political representatives have more educational degrees than voters in Konstanz and Heidelberg.

Clearly, cultural policy is not an important part of policy platforms. It thus follows from elementary spatial theory of voting that voters favor cultural projects less than their respective representatives. Figure 3 illustrates this point: The horizontal line describes policy preferences on the left-right scale. It is hard to determine whether the SPD is more rightwing or leftwing than the GREEN party, and the CDU is more rightwing or leftwing than the FDP. My assignment is based on the economic policy platforms and does not influence grouping the parties in leftwing and rightwing. The vertical line describes bourgeois preferences. The big ellipse describes the support of the distribution of the uniformly distributed bliss points of the voters. The small ellipse is the support of the distribution of the uniformly distributed bliss points of the representatives. ${ }^{20}$ Individual voters and political representatives vote in favor of the cultural policy project (blue dot: proposal), i.e. against the status quo if their bliss point is closer to the proposal than to the status quo. The dividing line between supporters and opponents of the cultural policy project is the perpendicular bisector of the distance between the proposal and the status quo. Voters and political representatives whose bliss point is above the perpendicular bisector (dividing line between supporters and opponents) vote in favor of the proposal. The majority of the political representatives (Sy, Gy, Cy, Fy) votes in favor of the proposal; while the majority of the voters ( $\mathrm{Sn}, \mathrm{Gn}, \mathrm{Cn}, \mathrm{Fn})$ votes against it. When representatives are more bourgeois than their voters, the cultural policy proposal is approved in a representative democracy and rejected in a direct democracy.

\footnotetext{
${ }^{20}$ I acknowlegde that Figure 3 does not consider the political representative of the DIE LINKE.
} 
Figure 3: Bourgeois and political party preferences and support for cultural policy

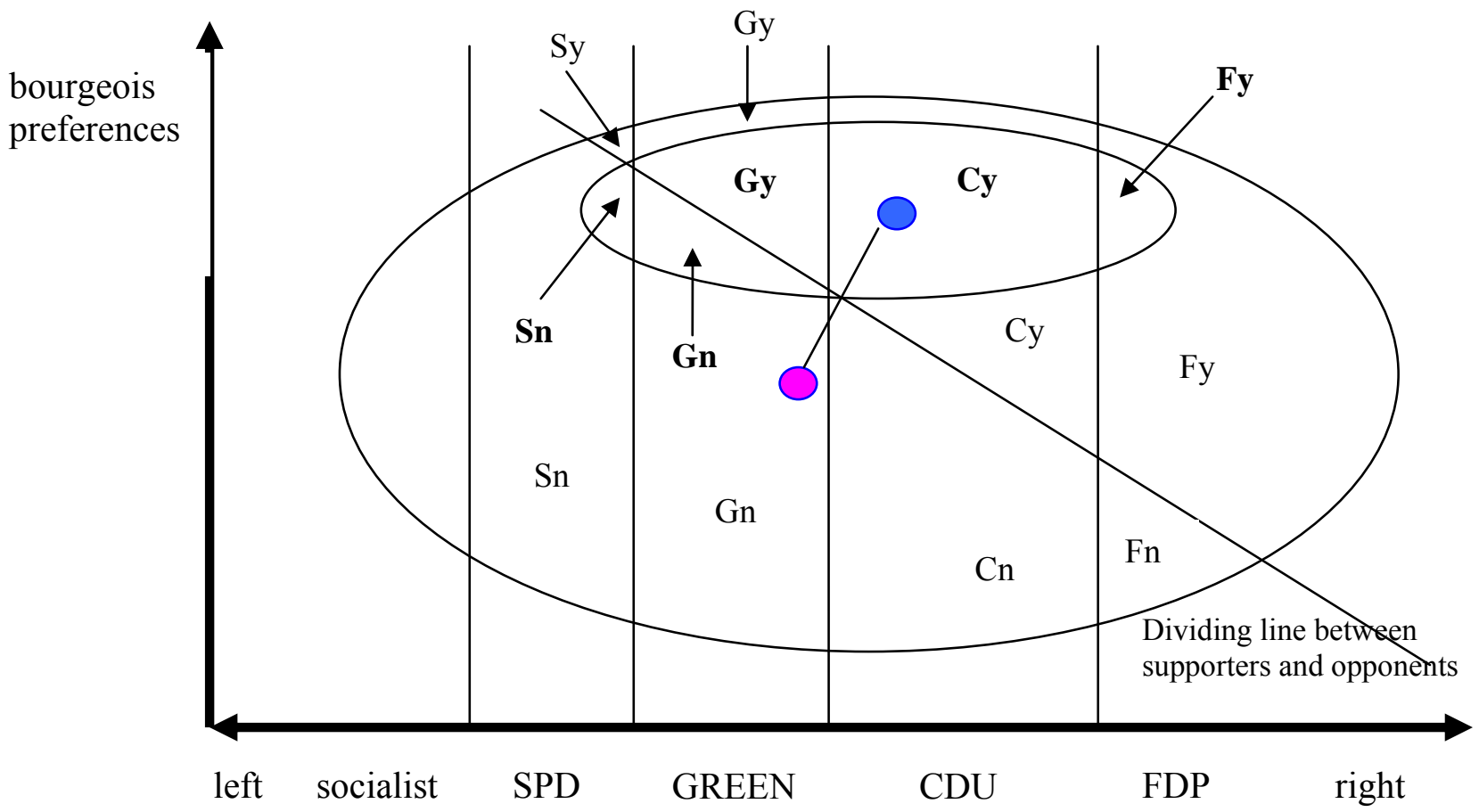

The big ellipse is the support of the distribution of the uniformly distributed bliss points of the voters

The small ellipse is the support of the distribution of the uniformly distributed bliss points of representatives

The blue dot is the proposal

The red dot is the status quo

Fn: FDP voters against proposal

Fy: FDP voter in favor of proposal

Fy: FDP representatives in favor of proposal

Fn: FDP representatives against proposal (none)

Cn: CDU voters against

Cy: CDU voters in favor

Cn: CDU representatives against (none)

Cy: CDU representatives in favor

Gn: Green voters against proposal

Gy: Green voter in favor of proposal

Gy: Green representatives in favor of proposal

Gn: Green representatives against proposal

Sn: SPD voters against proposal

Sy: SPD voter in favor of proposal

Sy: SPD representatives in favor of proposal (none)

Sn: SPD representatives against proposal 
My findings relate to studies that examine the nexus between voter preferences and political representation with US, Swedish and Swiss data (e.g., Levitt 1996; Gerber and Lewis 2004; Brunner et al. 2013; Ågren et al. 2006; Eichenberger et al. 2012; Portmann et al. 2012; Stadelmann et al. 2012; Portmann and Stadelmann 2013). To be sure, in contrast to the studies using US and Swiss data, council members in Konstanz and Heidelberg are not directly elected in the electoral districts, because the electoral districts are too small. The political parties provide candidate lists. The number of seats an individual party receives depends on the number of votes in all electoral districts (proportional representation). I therefore cannot draw any conclusions on how voter preferences in an individual electoral district influence decisions of the electoral districts deputy.

\section{Conclusion}

I have presented evidence on a political principal-agent problem regarding public spending and also environmental considerations associated with location. Resistance to public funding for the concert halls was particularly strong in electoral districts with large constituencies on the left. The direct-democratic vote against the concert halls is contrary to voting behavior of leftwing local representatives. ${ }^{21}$ As in general in parliamentary democracies, voter preferences are usually transmitted in Germany by political representation, not by direct-democratic routes. My findings show that, even at the regional or local level where preferences of politicians and voters might be expected to be closely aligned because of proximity of voters to their representatives, the voting behavior of politicians can be decoupled from the preferences of their constituencies. I propose that the decoupling occurs because political representatives are more bourgeois than their constituencies. In the cases studied in this paper, the presence of a political-agent problem due to differences in politicians' and voters' preferences did not result in the usual ability of politicians to have their way because of

\footnotetext{
${ }^{21}$ Peltzman (1992) shows that the US government has grown faster than voters wish.
} 
asymmetric information. The issues were sufficiently salient for voters to resist and to prevail. $^{22}$

\section{Acknowledgments}

I would like to thank Christian Bjørnskov, Chiara Dalle Nogare, Lars Feld, Arye Hillman, Heinrich Ursprung, the participants of the Economics Brown Bag Seminar at the University of Konstanz in April 2010 and of the Sociology Research Seminar at the University of Konstanz in May 2010, and two anonymous referees for their very helpful comments, hints, and suggestions. I am also grateful to Miriam Breckner, Carl Maier, Daniel Mannfeld, Ha Quyen Ngo, and Felix Weber for their excellent research assistance, Katja Bernhard from the Electoral Office Konstanz for providing the data on the voting outcomes, Eberhard Baier and Monika Köhler from the Statistical Office Konstanz for providing the data on religion and the map of the voting behavior, and Gerda Bühler from the Statistical Office in Heidelberg for providing all the data for Heidelberg and the map of voting behavior.

\footnotetext{
${ }^{22}$ The results in this paper are also revealing because policy platforms of the major political parties in Germany (SPD, CDU, FDP and Greens) have converged and the policies implemented by these parties have been very similar at the federal level (e.g., Potrafke 2012). By contrast, political ideology has been shown to influence German economic policy-making at the state and at the community level (e.g., Kauder and Potrafke 2013; Potrafke 2013). At these local levels, politicians implement more polarized policies to gratify the different policy preferences of voters. I have not considered why voters vote. Most plausibly, voters were expressing their identity (Hillman, 2010) or their indignation (Glazer 2008). Representatives were voting with the possibility of being decisive as a group in the smaller voting body of the local councils.
} 


\section{References}

Ågren, H., Dahlberg, M., \& Mörk, E. (2006). Do politicians' preferences correspond to those of the voters? An investigation of political representation. Public Choice, 130, 137-162.

Anselin, L. (1988). Spatial econometrics: methods and models. Dordrecht: Kluwer.

Barro, R.J. (1973). The control of politicians: an economic model. Public Choice, 14, 19-42.

Benito, B., Bastida, F., \& Vincente, C. (2013). Municipal elections and cultural expenditure. Journal of Cultural Economics, 37, 3-32.

Besley, T., Folke, O., Persson, T., \& Rickne, J. (2013). Gender quotas and the crisis of the mediocre man: theory and evidence from Sweden. Working Paper, Stockholm School of Economics.

Brooks, A.C. (2001). Who opposes government arts funding? Public Choice, 108, 355-367.

Brooks, A.C. (2004). In search of true public arts support. Public Budgeting and Finance, 24, 88-100.

Brunner, E., Ross, S.L., \& Washington, E. (2013). Does less income mean less representation? American Economic Journal: Economic Policy, forthcoming.

Clark, D.E., \& Kahn, J.R. (1988). The social benefits of urban cultural amenities. Journal of Regional Science, 28, 363-377.

Dalle Nogare, C., \& Galizzi, M.M. (2011). The political economy of cultural spending: evidence from Italian cities. Journal of Cultural Economics, 35, 203-231.

De Witte, K., \& Geys, B. (2011). Evaluating efficient public good provision: Theory and evidence from a generalized conditional efficiency model for public libraries. Journal of Urban Economics, 69, 319-327.

Eichenberger, R., Stadelmann, D., \& Portmann, M. (2012). A comparative analysis of the voting behavior of constituents and their representatives for public debts. Constitutional Political Economy, 23, 244-260.

Feld, L P., \& Kirchgässner, G. (2001). Does direct democracy reduce public debt? Evidence from Swiss municipalities. Public Choice, 109, 347-370.

Feld, L.P., Schaltegger, C.A., \& Schnellenbach, J. (2008). On government centralization and fiscal referendums. European Economic Review, 52, 611-645.

Feld, L P., Fischer, J.A.V., \& Kirchgässner, G. (2010a). The effect of direct democracy on income redistribution: evidence for Switzerland. Economic Inquiry, 48, 817-840.

Feld, L.P., Schaltegger, C.A, \& Schnellenbach, J. (2010b). The impact of referendums on the centralization of public good provision: a political economy approach. Economics of Governance, 11, 3-26. 
Feld, L P., Kirchgässner, G., \& Schaltegger, C.A. (2011). Municipal debt in Switzerland: New empirical results. Public Choice, 149, 49-64.

Findeisen, I., \& Hinz, T. (2011). Nutzung kultureller Einrichtungen und LebenszufriedenheitErgebnisse der Konstanzer Bürgerbefragung, Sommer 2010 - 3. Welle. Kooperationsprojekt Universität Konstanz, Arbeitsbereich Empirische Sozialforschung, Stadt Konstanz, Hauptamt - Statistik und Steuerungsunterstützung.

Getzner, M. (2002). Determinants of cultural public expenditures: an exploratory time series analysis for Austria. Journal of Cultural Economics, 26, 287-306.

Getzner, M. (2004). Voter preferences and public support for the performing arts: a case study for Austria. Empirica, 31, 27-42.

Gerber, E.R., \& Lewis, J.B. (2004). Beyond the median: Voter preferences, district heterogeneity, and political representation. Journal of Political Economy, 112, 1364-1383.

Glazer, A. (2008). Voting to anger and to please others. Public Choice, 134, 247-254.

Grossman, G., \& Helpman, E. (1994). Protection for sale. American Economic Review, 84, 833-850. Reprinted in: Congleton, R.D., Hillman, A.L., \& Konrad, K.A. (Ed.) (2008), Forty years of research in rent seeking 2, Applications: Rent seeking in practice (pp. 131-148). Berlin: Springer.

Hillman, A.L. (1982). Declining industries and political-support protectionist motives. American Economic Review, 72, 1180-1187. Reprinted in: Congleton, R.D., Hillman, A.L., \& Konrad, K.A. (Ed.) (2008), Forty years of research in rent seeking 2, Applications: Rent seeking in practice (pp. 105-112). Berlin: Springer.

Hillman, A.L. (2009). Public finance and public policy: Responsibilities and limitations of goverment. 2nd edtion. Cambridge, UK: Cambridge University Press.

Hillman, A.L. (2010). Expressive behavior in economics and politics. European Journal of Political Economy, 26, 403-418.

Hug, S. (2004). Occurrence and policy consequences of referendums: A theoretical model and empirical evidence. Journal of Theoretical Politics, 16, 321-356.

Hug, S. (2009). Some thoughts about referendums, representative democracy, and separation of powers. Constitutional Political Economy, 20, 251-266.

Hug, S., \& Sciarini, P. (2000). Referendums on European integration - Do institutions matter in the voter's decision? Comparative Political Studies, 33, 3-36.

Kauder, B., \& Potrafke, N. (2013). Government ideology and tuition fee policy: Evidence from the German states. CESifo Economic Studies, forthcoming. 
Katz-Gerro, T., Raz, S., \& Yaish, M. (2009). How do class, status, ethnicity, and religiosity shape cultural omnivorousness in Israel? Journal of Cultural Economics, 33, 1-17.

Levitt, S.D. (1996). How do senators vote? Disentangling the role of voter preferences, party affiliation, and senator ideology. American Economic Review, 86, 425-441.

Lewis, G.B., \& Rushton, M. (2007). Understanding state spending on the arts, 1976-99. State \& Local Government Review, 39, 107-114.

Matsusaka, J.G. (2005). The eclipse of legislatures: Direct democracy in the 21 st century. Public Choice, 124, 157-177.

Merzyn, W., \& Ursprung, H.W. (2005). Voter support for privatizing education: evidence self-interest and ideology. European Journal of Political Economy, 25, 33-58.

Noonan, D.S. (2007). Fiscal pressures, institutional context, and constituents: A dynamic model of states' arts agency appropriations. Journal of Cultural Economics, 31, 293-310.

Oberndorfer, U., \& Steiner, V. (2007). Generationen- oder Parteienkonflikt? Eine empirische Analyse der deutschen Hochschulausgaben. Perspektiven der Wirtschaftspolitik, 8, 165-183.

Peltzman, S. (1976). Toward a more general theory of regulation. Journal of Law and Economics, 19, 211-240.

Peltzman, S. (1992). Voters as fiscal conservatives. Quarterly Journal of Economics, 107, 327-361.

Pommerehne, W.W., \& Schneider, F. (1983). Private demand for public subsidies to the arts: a study in voting and expenditure theory. In: Shanahan, J.L., Hendon, W.S., Hilhorst, I. Th. H., \& Straalen, J. v. (Ed.), Economic support for the arts (pp. 53-65). Ohio: Akron University Press.

Portmann, M., Stadelmann, D., \& Eichenberger, R. (2012). District magnitude and representation of the majority's preferences: Evidence from popular and parliamentary votes. Public Choice, 151, 585-610.

Portmann, M., \& Stadelmann, D. (2013). Testing the median voter model and moving beyond its limits: Do characteristics of politicians matter? CREMA Working Paper, 2013-05.

Potrafke, N. (2011a). Public expenditures on education and cultural affairs in the West German states: does government ideology influence the budget composition? German Economic Review, 12, 124-145.

Potrafke, N. (2011b). Does government ideology influence budget composition? Empirical evidence from OECD countries. Economics of Governance, 12, 101-134.

Potrafke, N. (2012). Is German domestic social policy politically controversial? Public Choice, 153, 393-418. 
Potrafke, N. (2013). Economic freedom and political ideology across the German states. Regional Studies, 47, 433-449.

Revelli, F. (2008). Performance competition in local media markets. Journal of Public Economics, 92, 1585-1594.

Rushton, M. (2005). Support for earmarked public spending on culture: Evidence from a referendum in metropolitan Detroit. Public Budgeting and Finance, 25, 72-85.

Schneider, C.J. (2010). Fighting with one hand tied behind the back: political budget cycles in the German states. Public Choice, 142, 125-150.

Schulze, G.G. (2008). Tertiary education in a federal system: the case of Germany. In: Albert, M., Schmidtchen, D., \& Voigt, S. (Ed.), Scientific Competition (pp. 35-66). Tübingen: Mohr Siebeck.

Schulze, G.G., \& Rose, A. (1998). Public orchestra funding in Germany - an empirical investigation. Journal of Cultural Economics, 22, 227-247.

Schulze, G.G., \& Ursprung, H.W. (2000). La donna e mobile - or is she? Voter preferences and public support for the performing arts. Public Choice, 102, 131-149.

Seitz, H. (2000). Fiscal policy, deficits and politics of subnational governments: the case of The German Laender. Public Choice, 102, 183-218.

Stadelmann, D., Portmann, M., \& Eichenberger, R. (2012). Preference representation and the influence of political parties in majoritarian vs. proportional systems: an empirical test. CREMA Working Pape, 2012-03.

Stadt Heidelberg (2011). http://ww1.heidelberg.de/buergerinfo/infobi.asp. Accessed 07.10.11

Stadt Konstanz (2010a). Bürgerinformation - Konzert und Kongresshaus Konstanz. Pressebüro Konstanz. Werkzwei Print+Medien Konstanz GmbH.

Stadt Konstanz (2010b). Bürgerentscheid im März 2010 - Konzert- und Kongresshaus auf Klein-Venedig.

http://www.konstanz.de/rathaus/00749/02580/02613/index.html\#sprungmarke0_29. Accessed 10.04.10

Tridimas, G. (2007). Ratification through referendum or parliamentary vote: When to call a referendum? European Journal of Political Economy, 23, 674-692.

Tridimas, G. (2010). Referendum and the choice between monarchy and republic in Greece. Constitutional Political Economy, 21, 119-141.

Vaubel, R. (2006). Principal-agent problems in international organizations. Review of International Organizations, 1, 125-136. 
Vaubel, R., Dreher, A., \& Uğurlu, S. (2007). Staff growth in international organizations: A principal-agent problem? An empirical analysis. Public Choice, 133, 275-295.

Werck, K., Heyndels, B., \& Geys, B. (2008). The impact of 'central places' on spatial spending patterns: evidence from Flemish local government cultural expenditures. Journal of Cultural Economics, 32, 35-58. 


\section{Appendix: Electoral districts and boroughs in Konstanz (Source: Electoral Office Konstanz):}

Altstadt: Rathaus, Caritas Kindertagesstätte Arche (I), Caritas Kindertagesstätte Arche (II), Kinderhaus Paradies, Seniorenzentrum, Wallgutschule (I), Wallgutschule (II), Sozialgericht (I), Bürgersaal (Vorraum), Sozialgericht (II)

Paradies: Schänzlesporthalle (I), Schänzlesporthalle (II), Palmenhaus, Wallgutschule (III)

Petershausen-West: Treffpunkt Petershausen (I), Treffpunkt Petershausen (II), Treffpunkt Petershausen (III), Kindergarten Dorothea-von-der-Flüe (I), Kindergarten Dorothea-von-derFlüe (II), Zeppelin-Gewerbeschule (I), Kinderhaus Löwenzahn, Kinderkulturzentrum KIKUZ, Zeppelin-Gewerbeschule (II), Theodor-Heuss-Realschule (Neubau)

Petershausen-Ost: Grundschule Sonnenhalde, Kinderhaus Rappelkiste, Heinrich-SusoGymnasium (I), Heinrich-Suso-Gymnasium (II), Parktstift Rosenau

Königsbau: Petrus-Kindergarten, Uni-Laborgebäude V, Caritas-Zentrum Konradihaus (I), Caritas-Zentrum Konradihaus (II)

Allmannsdorf: Caritas Quartiersmanagement, Grundschule Allmannsdorf(I), Grundschule Allmannsdorf (II), Grundschule Allmannsdorf (III)

Staad: ARGE Sportboothafen, Kreuz-Kindergarten

Fürstenberg: Treffpunkt Chérisy (I), Treffpunkt Chérisy (II), Grund- und Hauptschule Berchen (I), Grund- und Hauptschule Berchen (II), Grund- und Hauptschule Berchen (III), Grundschule Wollmatingen, Grundschule Haidelmoos (I), Geschwister-Scholl-Schule, Grundschule Haidelmoos (II)

Wollmatingen: Regenbogenschule (I), Regenbogenschule (II), Kindergarten St. Martin, Gemeindezentrum St. Martin (I), Gemeindezentrum St. Martin (II)

Industriegebiet: Stadtwerke-Verwaltungsgebäude

Egg: Vermögen und Bau Ba.-Wü.-Amt KN

Litzelstetten: Schule Litzelstetten, Pfarrgemeindezentrum Peter und Paul (I), Pfarrgemeindezentrum Peter und Paul (II), Ortsverwaltung Litzelstetten

Dingelsdorf: Kindergarten St. Nikolaus (I), Kindergarten St. Nikolaus (II)

Dettingen: Grund- und Hauptschule Dettingen (I), Grund- und Hauptschule Dettingen (II), Grund- und Hauptschule Dettingen (III)

Wallhausen: Kindergarten Wallhausen 


\title{
Electoral districts and boroughs in Heidelberg (Source: Electoral Office Heidelberg):
}

\author{
Schlierbach: Turnhalle
}

Altstadt: Bürgeramt Rathaus, Hölderlin-Gymnasium (I), Hölderlin-Gymnasium (II), Hölderlin-Gymnasium (III), Hölderlin-Gymnasium (IV), Hölderlin-Gymnasium (V)

Bergheim: Volkshochschule (I), Volkshochschule (II)

Weststadt: Landhausschule (I), Landhausschule (II), Landhausschule (III), Landhausschule (IV), Landhausschule (V), Landhausschule (VI), Landhausschule (VII), Willy-HellpachSchule

Südstadt: Englisches Institut Heidelberg (I), Englisches Institut Heidelberg (II)

Rohrbach: Eichendorff-Turnhalle (I), Eichendorff-Turnhalle (II), Internationale Gesamtschule Heidelberg (I), Internationale Gesamtschule Heidelberg (II), Internationale Gesamtschule Heidelberg (III)

Kirchheim: Kurpfalzschule (I), Kurpfalzschule (II), Robert-Koch-Schule (I), Robert-KochSchule (II), Kurpfalzschule (III), Robert-Koch-Schule (III)

Pfaffengrund: Albert-Schweitzer-Schule (I), Albert-Schweitzer-Schule (II), AlbertSchweitzer-Schule (III)

Wieblingen: Fröbelschule Turnhalle (I), Fröbelschule Turnhalle (II), Fröbelschule Turnhalle (III), Johannes-Gutenberg-Schule

Handschuhsheim: Heiligenbergschule (I), Heiligenbergschule (II), Tiefburgschule Turnhalle (I), Tiefburgschule Pausenhalle, Tiefburgschule Turnhalle (II), Bürgeramt (I)

Neuenheim: Bürgeramt (II), Johannes-Kepler-Realschule (I), Johannes-Kepler-Realschule (II), Johannes-Kepler-Realschule (III), Bunsen-Gymnasium (I), Bunsen-Gymnasium (II)

Boxberg: Waldparkschule

Emmertsgrund: Grundschule (I), Grundschule (II)

Ziegelhausen: Neckarschule (I), Neckarschule (II), Neckarschule (III), Steinbachschule (I), Steinbachschule (II), Steinbachschule (III), Bürgerbegegnungsstätte 